(C) 2021, The Authors. Published by Elsevier Inc. and Fass Inc. on behalf of the American Dairy Science Association ${ }^{\circledR}$. This is an open access article under the CC BY-NC-ND license (http://creativecommons.org/licenses/by-nc-nd/4.0/).

\title{
Antibiotic use and potential economic impact of implementing selective dry cow therapy in large US dairies
}

\author{
Nina M. C. Hommels, ${ }^{1} \odot$ Fernanda C. Ferreira, ${ }^{2 *} \odot$ Bart H. P. van den Borne, ${ }^{1}{ }^{\oplus}$ and Henk Hogeveen ${ }^{1} \odot$ \\ ${ }^{1}$ Business Economics Group, Wageningen University and Research, Wageningen, 6700 EW the Netherlands \\ ${ }^{2}$ Veterinary Medicine Teaching and Research Center, School of Veterinary Medicine, University of California-Davis, Tulare 93274
}

\begin{abstract}
In this study, our objectives were to evaluate the economic feasibility of implementing selective dry cow therapy (SDCT) in large US herds and to estimate the potential reduction in antibiotic use around the dry period if SDCT management is adopted. Cow-level data were obtained from the Dairy Herd Improvement Association (AgriTech, Visalia, CA) and individual dairy herds in California. Logistic regression models were used to predict the incidence risk of subclinical and clinical mastitis in the subsequent lactation for 96 last test-day somatic cell score categories. Linear programming was used to optimize the costs of dry cow therapy in 3 simulated large US dairy herds with different bulk tank somatic cell counts (BTSCC). The objective function was aimed at minimization of the total cost of mastitis around the dry period (TCMD), under a varying constraint of the maximum percentage of cows dried off with antibiotics. A sensitivity analysis was performed on milk price, dry-off antibiotic price, and risk ratio of mastitis in the subsequent lactation when no antibiotics and only teat sealant was used at dry-off. For all situations, blanket dry cow therapy was more expensive than SDCT. In a herd with medium BTSCC, the TCMD was $\$ 54.7$ per primiparous dry cow and $\$ 58.5$ per multiparous dry cow annually. In the optimal economic situation where SDCT was used, only $30 \%$ of primiparous cows received antibiotics, leading to a TCMD of $\$ 52.4$ per primiparous dry cow, whereas $88 \%$ of multiparous cows received antibiotics, at a cost of $\$ 58.2$ per multiparous dry cow. This corresponded with an overall reduction of $29 \%$ in the use of antibiotics around the dry period in a conservative scenario. This study showed that it is economically feasible to reduce antibiotic use associated with dry cow therapy in large US dairy herds. This contributes to the efforts of reducing antibiotic use worldwide.
\end{abstract}

Received December 9, 2020.

Accepted March 24, 2021.

*Corresponding author: fcferreira@ucdavis.edu
Key words: selective dry cow therapy, antibiotic use, economics, optimization

\section{INTRODUCTION}

Mastitis in dairy cows is financially taxing. It leads to treatment costs, milk production losses, and premature culling of cows (Gonçalves et al., 2018; Hogeveen et al., 2019). For many years, blanket dry cow therapy (BDCT) has been a cornerstone in mastitis control (Dodd et al., 1969). This method involves administering long-acting antibiotics to all cows and quarters at dry-off, regardless of their infection status or incidence risk during the dry period (Scherpenzeel et al., 2014). The use of BDCT has been successful in reducing the prevalence of contagious pathogens, and it has contributed to the overall decrease in bulk tank SCC in many countries (Makovec and Ruegg, 2003). In the United States, $80 \%$ of dairy herds (and $94 \%$ of large dairy herds) have adopted BDCT as a management practice (USDA-NAHMS, 2014). In contrast, dairy herds in Nordic countries have been successfully using selective dry cow therapy (SDCT) since the 1970s (Dingwell et al., 2003; Østerås and Sølverød, 2009; Vanhoudt et al., 2018). With this approach, dairy cows are selected for antibiotic treatment based on their risk to have an IMI at the moment of dry-off, as this is an important risk factor for mastitis in the early subsequent lactation (Green et al., 2002; Scherpenzeel et al., 2018).

In Norway, SDCT has been implemented since 2005, and in 2009 the estimated percentage of cows receiving dry cow therapy was $0.05 \%$ (Østerås and Sølverød, 2009). In the Netherlands, the use of BDCT was prohibited in 2012, and SDCT has since been the default mastitis management at dry-off (Vanhoudt et al., 2018). The adoption of SDCT by Dutch dairy herds has not changed the SCC dynamics around the dry period, but it has significantly decreased the use of antibiotics by the dairy sector (Vanhoudt et al., 2018). However, early research on SDCT has shown that this approach may result in a greater risk of mastitis in the subsequent lactation (Scherpenzeel et al., 2014). More 
recent studies in the US and Canada, investigating the use of SDCT with teat sealants at dry-off, have shown promising results, with the overall incidence risk of mastitis at calving and in the early subsequent lactation being the same among the group of cows receiving BDCT or SDCT (Patel et al., 2017; Vasquez et al., 2018; Rowe et al., 2020a,b). In these studies, the herd and cow enrollment criteria varied. For instance, some studies enrolled only herds with average bulk tank SCC (BTSCC) below 250,000 cells/mL (Cameron et al., 2015; Vasquez et al., 2018; Rowe et al., 2020a). Selection of cows to receive antibiotics at dry-off varied based on a combination of different criteria, such as any SCC for the last 3 test-days $\leq 200,000$ cells $/ \mathrm{mL}$, an average SCC for the last 3 test-days $\leq 200,000$, the number of cases of clinical mastitis a cow had in her current lactation, or the last day of a case of clinical mastitis (Cameron et al., 2015; Patel et al., 2017; Vasquez et al., 2018; Rowe et al., 2020a). The reduced use of antibiotics at dry-off is not only an economic opportunity to reduce preventive costs of mastitis in dairy herds; it is also an opportunity to reduce the overall use of antibiotics in food animals (Scherpenzeel et al., 2014; Patel et al., 2017; Rowe et al., 2020a). Although no direct link has been proven between antibiotic use in the dry period and antibiotic resistance, more prudent use of antibiotics is recommended for every sector, in line with the precautionary principle and one health approach to reduce the problem of antimicrobial resistance, in both animals and humans (CDC, 2014; Aidara-Kane et al., 2018).

Economic studies on SDCT have shown that using SDCT can be economically beneficial (Berry and Hillerton, 2002; Huijps and Hogeveen, 2007; Scherpenzeel et al., 2016, 2018; Patel et al., 2017). The majority of these studies are from western Europe and are based on European inputs, management, and production parameters (Berry and Hillerton, 2002; Huijps and Hogeveen, 2007; Scherpenzeel et al., 2016, 2018). Furthermore, none of them considered the use of internal teat sealants in their analysis. The risk of new IMI during the dry period largely determines the economic success of SDCT (Huijps and Hogeveen, 2007). The use of internal teat sealants at dry-off has been reported as an efficient approach to prevent new IMI during the dry period (Huxley et al., 2002; Bradley et al., 2010; Dufour et al., 2019).

In the US, $71 \%$ of all operations are reported to use an internal teat sealant on at least some cows at dryoff, with $57 \%$ of large herds using it in all cows (USDANAHMS, 2014). Large herds are defined as herds with 500 or more cows (USDA, 2018). These herds may have overall better mastitis management, as shown by their overall lower BTSCC (USDA-NAHMS, 2014). There- fore, an economic analysis, considering the management inputs and practices of large US herds, is warranted. The objectives of this study were (1) to evaluate the economic feasibility of implementing SDCT with the use of teat sealant in US herds, and (2) to estimate the potential reduction in antibiotic use via SDCT.

\section{MATERIALS AND METHODS}

\section{Data}

To estimate the association between SCC at dry-off with the probability of clinical and subclinical mastitis in the next lactation, we used 2 large data sets. Data set 1 consisted of milk production recording data from the DHIA, obtained from AgriTech (Visalia, CA). We determined the number of lactating cows for each testday for each herd, and, consequently, herd size was calculated as the average of the number of lactating cows over the test-days (Ferreira et al., 2020). Before editing, this data set contained 7,344,035 lactation records from a total of 746 dairy herds in the western US. Herds with less than 500 cows, and test-day records before 10 DIM, with SCS $<0$ or $>10$, or daily milk yield $<0$ or $>150 \mathrm{~kg}$, were removed. Lactations without SCS information $(2,090,240)$, from breeds other than Holstein $(875,680)$, without a subsequent calving date $(2,658,696)$, that started before $2009(110,712)$, from cows of which the last test-day was $<30$ and $>120 \mathrm{~d}$ before the next calving date $(644,146)$, and from cows of which the first test-day in the subsequent lactation was missed or was above 50 DIM $(52,342)$, were excluded. Eventually, data set 1 contained 912,219 lactations from 527 dairy herds (Washington: 15, Oregon: 39, and California: 423), with first calving dates between Jan. 1, 2009, and Dec. 4, 2017. In our final data set, $49 \%$ of the cows were primiparous and $51 \%$ were multiparous. For every test-day in the final data set, the following variables were available: state; herd; cow identification number; calving date; parity (recorded as primiparous or multiparous); test-day milk, protein, and fat yields; and SCS.

Using data set 1 , subsequent lactations were combined to create new records. Every record consisted of the results of the last test-day before dry-off and the first test-day after calving (if calving occurred within the first 10 to $50 \mathrm{~d}$ postpartum). The SCS at the last test-day before dry-off was categorized into 96 categories from 0.1 to 9.6 , with increments of 0.1 units. When the SCS was $\geq 4$ (SCC $\geq 200,000$; Schukken et al., 2003), the cow was considered as having subclinical mastitis (SCM). It is known that $94 \%$ and $71 \%$ of the herds in the US use BDCT and teat sealants (USDANAHMS, 2014); therefore all herds in data set 1 were 
assumed to use BDCT in combination with an internal teat sealant.

The occurrence of clinical mastitis (CM) was not recorded in data set 1 . Therefore, additionally, data set 2 consisted of herd-level data from a convenience sample of 6 Holstein dairy herds located in Tulare County, California, known for good health record-keeping, including CM occurrence. These herds were included in data set 1 . Data were obtained through herd management systems (DairyComp 305, Valley Agricultural Software). Herds 1 to 6 contributed to $5,232,8,721,16,748,32,516,5,144$, and 31,667 lactation records, respectively. In this data set, $42 \%$ of the cows were primiparous and $58 \%$ multiparous. Calving date, test-day information, records of individual cow CM occurrence, and parity (primiparous or multiparous), from 100,028 lactations of cows calving between 2009 and 2017, were obtained. All 6 dairy herds used BDCT in combination with internal teat sealant as their dry cow management strategy. Cases of CM were identified and recorded by herd personnel. Therefore, first CM cases or treatments for cows up to 90 DIM were merged to identify the incidence risk of the first case of CM in early subsequent lactation in association with the last test-day SCS. Similarly to data set 1, the SCS at each cow's last test-day before dry-off was categorized into 96 categories, with 0.1 incremental increases. Only a small number of cows were sorted into high SCS categories in data set 2 (representing $2 \%$ of the total lactations), and therefore it was decided that from SCS 7 onward, cows would be grouped in a unique SCS category for this data set.

\section{Statistical Analysis and Logistic Regression}

Descriptive statistics were calculated for the herds in each data set. The incidence risk of SCM in the first test-day (data set 1) and the first case of CM up to 90 DIM (data set 2) per herd was calculated by summing all cows with a case of SCM in their first test-day of the subsequent lactation (from 10 to to 50 DIM) or 1 or more reported cases of CM (classified as a new case only if they were separated by an interval of $14 \mathrm{~d}$ ) in the first 90 DIM divided by the total number of cows that were dried off in each SCS category.

The incidence risk of SCM or CM in the subsequent lactation was estimated using a generalized linear mixed model with a logit link, as follows:

$$
\operatorname{logit}\left(\mathrm{Y}_{\mathrm{ijcp}}\right)=\alpha+\operatorname{SCS}_{\mathrm{c}}+\operatorname{parity}_{\mathrm{p}}+\operatorname{herd}_{\mathrm{i}}+\varepsilon_{\mathrm{ijcp}},
$$

where $\mathrm{Y}$ is the incidence risk of $\mathrm{SCM}$ or $\mathrm{CM}$ in the early subsequent lactation for cow $\mathrm{j}$ in herd $\mathrm{i}$ with the SCS category at the last test-day before dry-off c and parity p. The interaction term between parity and SCS was not significant and was therefore removed from the model. Herd was added as a random intercept to the model to correct for clustering of cows within herds. The predicted incidence risk of cows having SCM or CM was calculated for each combination of SCS and parity category based on the final regression models. All analyses were performed in $\mathrm{R}$ using the lme4 package ( $\mathrm{R}$ Core Team, 2019).

\section{Total Cost of Mastitis Around the Dry Period}

All prices are in US\$. The total costs of mastitis around the dry period (TCMD) was calculated as follows:

$$
\mathrm{TCMD}=\mathrm{C}_{\mathrm{p}, \mathrm{c}, \mathrm{a}}^{\mathrm{DCT}}+\mathrm{C}_{\mathrm{p}, \mathrm{c}, \mathrm{a}}^{\mathrm{SCM}}+\mathrm{C}_{\mathrm{p}, \mathrm{c}, \mathrm{a}}^{\mathrm{CM}}
$$

where $\mathrm{p}$ is parity, $\mathrm{c}$ is the SCS class at the last test-day before dry-off, and a is the use or not of antibiotics at dry-off. $\mathrm{C}_{\mathrm{p}, \mathrm{D}, \mathrm{a}}^{\mathrm{DCT}}$ are the costs for dry cow therapy (DCT), $\mathrm{C}_{\mathrm{p}, \mathrm{c}, \mathrm{a}}^{\mathrm{SCM}}$ are the costs of SCM associated with the dry period, and $\mathrm{C}_{\mathrm{p}, \mathrm{c}, \mathrm{a}}^{\mathrm{CM}}$ are the costs of $\mathrm{CM}$ associated with the dry period. $\mathrm{C}_{\mathrm{p}, \mathrm{c}, \mathrm{a}}^{\mathrm{DCT}}$ was calculated as follows:

$$
\mathrm{C}_{\mathrm{p}, \mathrm{c}, \mathrm{a}}^{\mathrm{DCT}}=\mathrm{N}_{\mathrm{p}, \mathrm{c}, \mathrm{a}=1} \times 4 \times \operatorname{Pr}^{\mathrm{ABD}}+\mathrm{N}_{\mathrm{p}, c, \mathrm{a}} \times 4 \times \operatorname{Pr}^{\mathrm{TS}}+\mathrm{N}_{\mathrm{p}, \mathrm{c}, \mathrm{a}} \times \mathrm{T}^{\mathrm{DCT}} \times \operatorname{Pr}^{\mathrm{L}},
$$

where $\mathrm{p}, \mathrm{c}$, and a are as previously described, $\mathrm{N}$ is the number of cows $(\mathrm{a}=1$ if they receive antibiotics at dry-off), $\operatorname{Pr}^{\mathrm{ABD}}, \operatorname{Pr}^{\mathrm{TS}}$, and $\operatorname{Pr}^{\mathrm{L}}$ are respectively the prices for dry-off antibiotics (\$/tube), teat sealant $(\$ /$ tube), and labor (per hour), $\mathrm{T}^{\mathrm{DCT}}$ is the labor time (in hours) required to dry off 1 cow. Because all cows are treated with internal teat sealant, it is assumed that the additional labor time to treat cows with antibiotics during drying off is negligible. We also assumed that the process of selecting cows to be treated or not can be automated, and therefore no extra labor for this task was considered.

The costs of SCM associated with the dry period, $\mathrm{C}_{\mathrm{p}, \mathrm{c}, \mathrm{a}}^{\mathrm{SCM}}$, is calculated as follows:

$$
\mathrm{C}_{\mathrm{p}, \mathrm{c}, \mathrm{a}}^{\mathrm{SCM}}=\mathrm{N}_{\mathrm{p}, \mathrm{c}, \mathrm{a}} \times \mathrm{P}_{\mathrm{p}, \mathrm{c}, \mathrm{a}}^{\mathrm{SCM}} \times \mathrm{MPL}^{\mathrm{SCM}} \times \mathrm{D}^{\mathrm{MPL}} \times \operatorname{Pr}^{\mathrm{M}},
$$

where $\mathrm{N}$ is the number of cows receiving antibiotics or not at dry-off according to their last test-day SCS category, $\mathrm{P}_{\mathrm{p}, \mathrm{s}, \mathrm{a}}^{\mathrm{SCM}}$ is the probability of SCM after calving for each category of SCS at dry-off as derived from data set 
$1, \mathrm{MPL}^{\mathrm{SCM}}$ is the daily milk production loss due to SCM after calving $(\mathrm{kg} / \mathrm{d}), \mathrm{D}^{\mathrm{MPL}}$ is the duration of milk production losses (in days), $\operatorname{Pr}^{\mathrm{M}}$ is the marginal milk price, and p, c, and a are as previously described. No additional costs due to culling, antibiotic treatment, or loss of milk quality were considered.

The costs for CM associated with the dry period, $\mathrm{C}_{\mathrm{p}, \mathrm{c}, \mathrm{a}}^{\mathrm{CM}}$, are calculated as follows:

$$
\begin{aligned}
& \mathrm{C}_{\mathrm{p}, \mathrm{c}, \mathrm{a}}^{\mathrm{CM}}=\mathrm{N}_{\mathrm{p}, \mathrm{c}, \mathrm{a}} \times \mathrm{P}_{\mathrm{p}, \mathrm{c}, \mathrm{C}}^{\mathrm{CM}} \times \\
& \left(\mathrm{Pr}^{\mathrm{ABL}} \times \mathrm{D}^{\mathrm{Tr}}+\mathrm{MPL}^{\mathrm{Tr}} \times \mathrm{Pr}^{\mathrm{MC}}+\mathrm{T}^{\mathrm{Tr}} \times \operatorname{Pr}^{\mathrm{L}} \times \mathrm{D}^{\mathrm{Tr}}+\mathrm{MPL}^{\mathrm{CM}} \times \mathrm{PP}^{\mathrm{M}}+\mathrm{C}^{\mathrm{Cul}}\right),
\end{aligned}
$$

where $\mathrm{N}$ is the number of cows receiving or not antibiotics at dry-off according to their last test-day SCS category, $\mathrm{P}_{\mathrm{p}, \mathrm{c}, \mathrm{a}}^{\mathrm{CM}}$ is the probability of $\mathrm{CM}$ after calving derived from data set $2, \operatorname{Pr}^{\mathrm{ABL}}$ is the cost for intramammary antibiotic treatment for lactating cows (\$/tube), $\mathrm{D}^{\mathrm{TR}}$ is the number of treatment days, MPL ${ }^{\operatorname{Tr}}$ and $\mathrm{MPL}^{\mathrm{CM}}$ are respectively the total milk production losses due to milk withdrawal $(\mathrm{kg})$ and total reduced milk production due to a case of CM throughout the lactation (kilograms per lactation), $\operatorname{Pr}^{\mathrm{MC}}$ is the marginal cost of discarded milk (assuming this milk is used to feed calves), cost of $\mathrm{T}^{\operatorname{Tr}}$ is the time (h) needed for treatment (per day), $\mathrm{C}^{\mathrm{Cul}}$ is the cost of culling, and $\operatorname{Pr}^{\mathrm{M}}, \operatorname{Pr}^{\mathrm{L}}, \mathrm{p}, \mathrm{c}$, and a are as previously described.

Inputs and assumptions used for the calculation of $\mathrm{C}_{\mathrm{p}, \mathrm{c}, \mathrm{a}}^{\mathrm{DCT}}, \mathrm{C}_{\mathrm{p}, \mathrm{c}, \mathrm{a}}^{\mathrm{SCM}}$, and $\mathrm{C}_{\mathrm{p}, \mathrm{c}, \mathrm{a}}^{\mathrm{CM}}$ are shown in Table 1. Costs of $\mathrm{CM}$ were calculated based on an expansion of the partial budget model proposed by Huijps et al. (2008) and Rollin et al. (2015). Default milk price was $\$ 0.40$, representing the average milk price for the US from 2015 to 2019 (USDA-ERS, 2019). We assumed that 1 case of CM would be treated for $3 \mathrm{~d}$ with $6 \mathrm{~d}$ of milk withdrawal, 1 quarter would be affected per case of CM, and only the affected quarter would receive antibiotics. We assumed that $80 \%$ of the withdrawn milk would be used to feed calves and substituted for milk replacer with a cost representing $92.4 \%$ of the milk price. Therefore, the marginal milk price for discarded milk $\left(\mathrm{Pr}^{\mathrm{MC}}\right)$ was $\$ 0.10 / \mathrm{kg}$ (Rollin et al., 2015). Labor cost was $\$ 15 / \mathrm{h}$ (CA-DIR, 2020), and labor time associated with milking and treating mastitic cows was $10 \mathrm{~min} / \mathrm{d}$ (Rollin et al., 2015). To estimate milk losses due to CM, we assumed that a Holstein cow produced, on average, 11,604 $\mathrm{kg}$ of milk in a 305-d lactation (CDCB, 2017). Using data set 2, we calculated the median DIM of the first case of CM (45 DIM). Following the adjustments for milk losses after a case of CM proposed by Wilson et al. (2004), 1 case of CM resulted in decreased milk produc- tion of $758.9 \mathrm{~kg}$. We assumed that a cow consumes 0.71 Mcal to produce $1 \mathrm{~kg}$ more milk (Rollin et al., 2015), and that $1 \mathrm{~kg}$ of DM of a well-balanced TMR contains 1.7 Mcal (NRC, 2001). We therefore assumed that a cow consumed $0.4 \mathrm{~kg}$ of DM per $1 \mathrm{~kg}$ more milk, which came at a cost of $\$ 0.28 / \mathrm{kg}$ of DMI (Rollin et al., 2015). Therefore, the marginal milk price for milk not produced $\left(\operatorname{Pr}^{\mathrm{M}}\right)$ was $\$ 0.29 / \mathrm{kg}$.

Finally, the risk ratio of culling due to a case of $\mathrm{CM}$ at 45 DIM was 1.8 throughout the lactation (Gröhn et al., 1998; Rollin et al., 2015). Using the populationattributable fraction of 0.07 (Gröhn et al., 1998; Rollin et al., 2015), and the probability of CM in the subsequent lactation up to $90 \mathrm{~d}$ in lactation $(9.5 \%$, from data set 2), we calculated the fraction of the culling risk attributable to mastitis (0.07; Rollin et al., 2015), and the difference in culling cost due to mastitis $\left(\mathrm{C}^{\mathrm{CUL}}\right.$, $\$ 29.7$ per case). The cost of raising a heifer was assumed to be $\$ 2,016$ (Overton and Dhuyvetter, 2020). The cull cow price was $\$ 1.4 / \mathrm{kg}$ (USDA-NASS, 2020). The average weight of a culled cow was $636 \mathrm{~kg}$ (Rollin et al., 2015). We calculated the depreciation cost per year of productive life for cows with and without mastitis using a straight-line approach, by subtracting the salvage value of a culled cow from the cost of raising a heifer and dividing it by the cow's 2.8 years of productive life, calculated considering an average cull rate of $35 \%$. The interest rate was $5 \%$, and $\mathrm{C}^{\mathrm{CUL}}$ was the difference between the culling cost of cows with and without mastitis. The total cost of 1 case of $\mathrm{CM}$ was $\$ 295.26$.

\section{Optimization Model for Selective Dry Cow Therapy}

To find the economic optimal (minimal TCMD) use of antibiotics at dry-off given costs of use of antibiotics at dry-off, costs of mastitis associated with dry-off, and probabilities of CM and SCM associated with the use of antibiotics at dry-off for the SCS classes, an existing linear programming (LP) model developed in Microsoft Excel (Microsoft Corporation, 2013; Scherpenzeel et al., 2018) was adapted. This LP model allocates the use of antibiotics for the cows in each SCS and parity class in such a way that the TCMD is minimized. Constraints can be added to the optimization model, for instance, regarding the maximum amount of antibiotics [in animal-defined daily dosages (ADDD)] that is allowed to be used for mastitis associated with the dry period. To carry out this allocation of antibiotics at dry-off, all cows $(\mathrm{N})$ that need to be dried off in a herd in 1 yr were grouped as follows: 2 parity classes $\mathrm{p}$ [parity $=1$ (primiparous) or 2 (multiparous)], 96 SCS at last test-day classes c $[\mathrm{c}=1(\mathrm{SCS} 0.1), \ldots, 96$ (SCS 
9.6)], and 2 dry-off scenarios a $[\mathrm{a}=1$ (antibiotics at dry-off) or 2 (no antibiotics at dry-off)]. For cows in each of these classes, the optimization model will decide to use antibiotics or not. The simplex algorithm was used for the optimization.

The objective function of the LP model was to minimize the TCMD. In other words, we did not provide the SCS thresholds for the use of antibiotics at dry-off, but the LP model determined the thresholds for the use of antibiotics for cows with different parities in such a way that TCMD was minimized, given the costs of each of the alternatives. The binary variable describing the use of antibiotics at dry-off was the decision variable to be optimized. The objective function was

$$
\text { Minimize TCMD }=\sum_{\mathrm{p}=1}^{2} \sum_{\mathrm{c}=1}^{96} \sum_{a=1}^{2}\left(\mathrm{C}_{\mathrm{p}, \mathrm{c}, \mathrm{a}}^{\mathrm{DCT}}+\mathrm{C}_{\mathrm{p}, \mathrm{c}, \mathrm{a}}^{\mathrm{SCM}}+\mathrm{C}_{\mathrm{p}, \mathrm{c}, \mathrm{a}}^{\mathrm{CM}}\right) \times \mathrm{N}_{\mathrm{p}, \mathrm{c}, \mathrm{a}}
$$

and was subject to the following constraints:

$$
\begin{gathered}
\mathrm{N}_{\mathrm{p}, \mathrm{c}, \mathrm{a}} \geq 0 \\
0 \leq \mathrm{N}_{\mathrm{p}, \mathrm{c}, \mathrm{a}=1} \leq \mathrm{N}_{\mathrm{p}, \mathrm{c}, \mathrm{a}} \\
0 \leq \mathrm{N}_{\mathrm{p}, \mathrm{c}, \mathrm{a}=2} \leq \mathrm{N}_{\mathrm{p}, \mathrm{c}, \mathrm{a}} \\
\mathrm{N}_{\mathrm{p}, \mathrm{c}}=\mathrm{N}_{\mathrm{p}, \mathrm{c}, \mathrm{a}=1}+\mathrm{N}_{\mathrm{p}, \mathrm{c}, \mathrm{a}=2} \\
\mathrm{~N}_{\mathrm{p}, \mathrm{c}, \mathrm{a}=1} \leq \mathrm{N}_{\mathrm{p}, \mathrm{c}, \mathrm{a}} \times \mathrm{AB},
\end{gathered}
$$

where TCMD represents the total cost of mastitis associated with the dry period in $1 \mathrm{yr}, \mathrm{C}_{\mathrm{p}, \mathrm{c}, \mathrm{a}}^{\mathrm{DCT}}, \mathrm{C}_{\mathrm{p}, \mathrm{c}, \mathrm{a}}^{\mathrm{SCM}}$, and $\mathrm{C}_{\mathrm{p}, \mathrm{c}, \mathrm{a}}^{\mathrm{CM}}$ respectively represent the costs of $\mathrm{DCT}$, costs of $\mathrm{SCM}$, and costs of CM for cows in 2 parity classes $\mathrm{p}$ [p $=1$ (primiparous) or 2 (multiparous)], 96 classes of SCS at the last test-day c $[\mathrm{c}=1$ (SCS 0.1$), \ldots, 96$ (SCS 9.6)], and 2 antibiotics at dry-off classes a $[\mathrm{a}=1$ (antibiotics at dry-off) or 2 (no antibiotics at dry-off)], $\mathrm{N}_{\mathrm{p}, \mathrm{c}, \mathrm{a}}$ represents the number of cows in each class, and

Table 1. Input values and assumptions used in the calculations of dry cow therapy cost $\left(\mathrm{C}^{\mathrm{DCT}}\right)$, subclinical mastitis cost $\left(\mathrm{C}^{\mathrm{SCM}}\right)$, and clinical mastitis costs $\left(\mathrm{C}^{\mathrm{CM}}\right)$

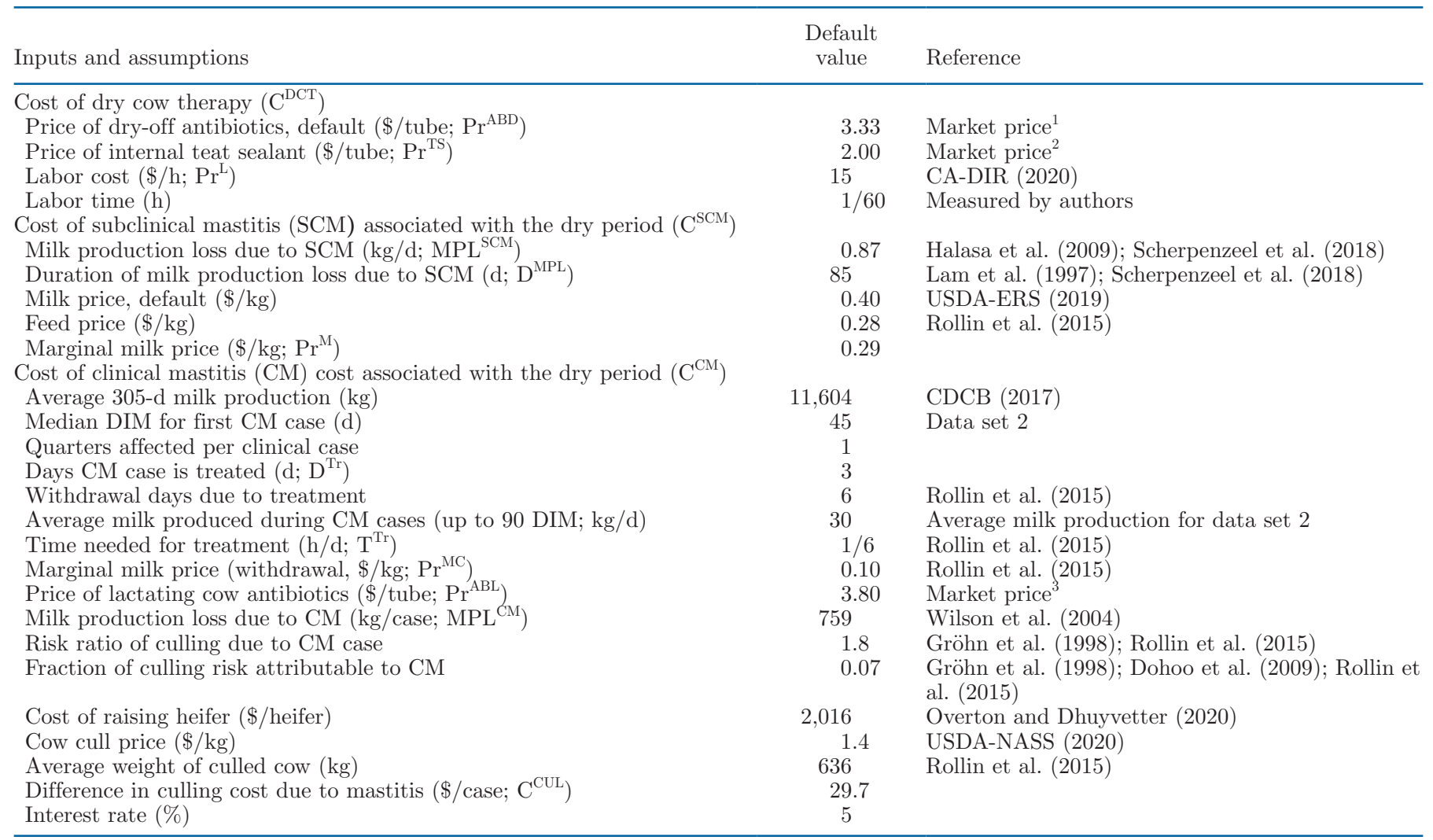

${ }^{1}$ Average market price for dry cow antibiotics (Tomorrow Dry Cow, Boehringer Ingelheim; Spectramast DC, Zoetis; and Go-Dry, Hanford's US Vet) sold in California in January 2020.

${ }^{2}$ Average market price for internal teat sealants (Orbeseal, LockOut, and ShutOut) sold in California in January 2020.

${ }^{3}$ Average market price for lactating cow antibiotics (PolyMast, Spectramast LC, and Masti-Clear) sold in California in January 2020. 
$\mathrm{AB}$ is the proportion of cows allowed to be dried off with antibiotics.

\section{Antibiotic Use}

Antibiotic use was expressed as the calculated number of ADDD. For dairy cows, this indicates how many days per year an average cow in the herd is treated with antibiotics (Kuipers et al., 2016). A cow dried off with antibiotics contributed to 4 cow-defined daily dosages, in tubes. A case of $\mathrm{CM}$ contributed to $3 \mathrm{ADDD}$ (in tubes). Therefore, the total ADDD was calculated as the sum of the ADDD from cows dried off with antibiotics plus the incidence of $\mathrm{CM}$ in the subsequent lactation according to each last test-day SCS classes times the ADDD for 1 case of CM up to 90 DIM treated with antibiotics (Scherpenzeel et al., 2018).

\section{Simulated Herds and Inputs}

Based on data set 1, 3 simulated herds of 1,000 cows with different BTSCC levels were created as follows. Cull rate was assumed to be $35 \%$ for both primiparous and multiparous, and $90 \%$ of the cows that were culled were not dried off (Scherpenzeel et al., 2018). Therefore, $32 \%$ of the cows were not dried off due to replacement. Thus, the average number of primiparous and multiparous cows dried off in 1 yr was 235 and 443, respectively.

For each herd and each test-day in data set 1, the weighted average BTSCC was calculated by transforming individual SCS into SCC using the formula SCC $=2^{\mathrm{SCS}-3} \times 100,000$ (Norman et al., 2000), multiplying it by the cow's milk production, and dividing it by the total milk production on that test-day. The annual BTSCC was calculated per herd and subsequently averaged across multiple years to have a point estimate per herd. Based on this distribution, we defined 3 levels of BTSCC: low (herds from percentiles 5-25; BTSCC of 121,009-164,710 cells/mL), medium (herds from percentiles 40-60; BTSCC 188,782-222,688 cells/ $\mathrm{mL}$ ), and high (herds from percentiles 75-95; BTSCC 257,941-373,702 cells/mL). For each of these groups, we calculated the percentage of primiparous and multiparous cows dried off in each SCS category (0.1-9.6). We weigthed the number of cows in each SCS category by the incidence risks of SCM and CM from the regression models to calculate the overall incidence risk of SCM and CM in herds with low, medium, and high BTSCC.

The predicted incidence risk of SCM and CM in the subsequent lactation from the regression models were used as inputs in the LP model when antibiotics and teat sealants were used at dry-off. Because all dairy herds contributing to our data sets used BDCT with internal teat sealant at dry-off, we assumed that teat sealants were still applied to all 4 quarters of all cows when no antibiotics were used during dry-off. A risk ratio was assumed, based on results of Scherpenzeel et al. (2018), to account for the incidence of SCM and CM when no antibiotics and only teat sealants were used versus when antibiotics and teat sealants were used. We used the median risk ratio values for SCM and CM for primiparous (2.0 and 1.3, respectively), and multiparous (1.7 and 1.6, respectively) for the scenarios when only internal teat sealant was used (Scherpenzeel et al., 2018). Although Scherpenzeel et al. (2018) did not assume the use of internal teat sealant at dry-off, we opted for this more conservative approach as our default scenario.

\section{Sensitivity Analysis}

To evaluate the effects of varying milk prices, the cost of dry-off tubes, and the risk ratios applied to cows not receiving antibiotics at dry-off, we performed a sensitivity analysis in the optimization model. Milk price was varied from $\$ 0.30 / \mathrm{kg}$ to $\$ 0.50 / \mathrm{kg}$ to reflect the lowest and highest milk prices observed in a 10-yr period in the US (USDA-ERS, 2019). Dry-off tube prices were $\$ 2.0, \$ 3.3$, and $\$ 5.5$ per tube, to reflect the range in market values of the most common products sold in California in Jan. 2020 (Table 1). The sensitivity analysis for the risk ratios for the incidence of SCM and $\mathrm{CM}$ in the subsequent lactations were derived from cure risks reported in the literature when teat sealants were used (Supplemental File S1, https://doi.org/10.6084/ m9.figshare.14428202). Risk ratios were 1 (indicating no increased risk of mastitis when no antibiotics were administered during the dry period), 1.3 (Huxley et al., 2002; Bradley et al., 2010), 2.0 (Huxley et al., 2002), and 2.55 (Halasa et al., 2009).

\section{RESULTS}

\section{Herd Characteristics and Incidence Risks of Subclinical and Clinical Mastitis}

In data set 1 , average herd size was 2,440 cows (5th percentile: 525 , median: 1,917, 95th percentile: 5,717). Last test-day milk production averaged $25 \mathrm{~kg}$ (5th percentile: 11, median: 25, 95th percentile: 38 ), and last test-day SCS averaged 2.7 (5th percentile: 0.1, median: $2.6,95$ th percentile: 5.5 ). The average incidence risk of SCM at the first test-day in the subsequent lactation for the herds in data set 1 was $17 \%$. In data set 2 , the last test-day before dry-off SCS average was 2.3 (5th 
percentile: 0.1 , median: 2 , 95th percentile: 6 ), and the incidence risk of $\mathrm{CM}$ in the first $90 \mathrm{~d}$ of the subsequent lactation was $9.5 \%$.

\section{Regression Analysis}

Parity and last test-day SCS category were significantly associated with the incidence of SCM and CM in the subsequent lactation $(P<0.001$; Supplemental Table S1). The predicted incidence risks of SCM and $\mathrm{CM}$ in the first test-day (SCM) or up to 90 DIM (CM) of the subsequent lactation for primiparous and multiparous according to the last test-day SCS category are shown in Figure 1. As SCS at the last test-day increases, the incidence risks of both SCM and $\mathrm{CM}$ increases for primiparous and multiparous cows.

\section{Optimization Models}

The distribution of cows per last test-day SCS category varied in dairy herds with low, medium, and high BTSCC (Figure 2). For instance, in low-BTSCC dairy herds, $98 \%$ of primiparous cows had a last test-day SCS below 4.0 (200,000 cells $/ \mathrm{mL})$, whereas in herds with high BTSCC, $79 \%$ of primiparous cows were in this same category.

Total Cost of Mastitis Around the Dry Period. For low-BTSCC herds, under economic optimal allocation of antibiotics at dry-off, the TCMD was $\$ 37,264$ / herd per year ( $\$ 49$ and $\$ 59 /$ dry cow primiparous and dry cow multiparous, Table 2 ), which was $\$ 773 /$ herd per year less when compared with a BDCT scenario. In this scenario, $22 \%$ of the primiparous and $89 \%$ of the multiparous cows received antibiotics at dry-off. Medium-BTSCC herds had an economic optimal TCMD of $\$ 38,085 /$ herd per year ( $\$ 52$ and $\$ 58 /$ dry cow primiparous and multiparous), with $30 \%$ and $88 \%$ of the primiparous and multiparous cows receiving antibiotics at dry-off. For the medium-BTSCC herds, the total difference between the economic optimal and the BDCT scenarios was $\$ 696 /$ herd per year. For high-BTSCC herds, TCMD in the economic optimal scenario was $\$ 39,317 /$ herd per year ( $\$ 55$ and $\$ 59 /$ dry cow primiparous and multiparous), with $38 \%$ and $89 \%$ of the primiparous and multiparous cows receiving antibiotics at dry-off. The difference between the economic optimal TCMD and the BDCT scenarios was the smallest for high-BTSCC herds, a total of $\$ 569 /$ herd per year. Limiting the percentage of cows receiving antibiotics at dry-off changed the TCMD differently for herds with low, medium, and high BTSCC. Overall, applying BDCT or not using any antibiotics at all increased the cost of mastitis around
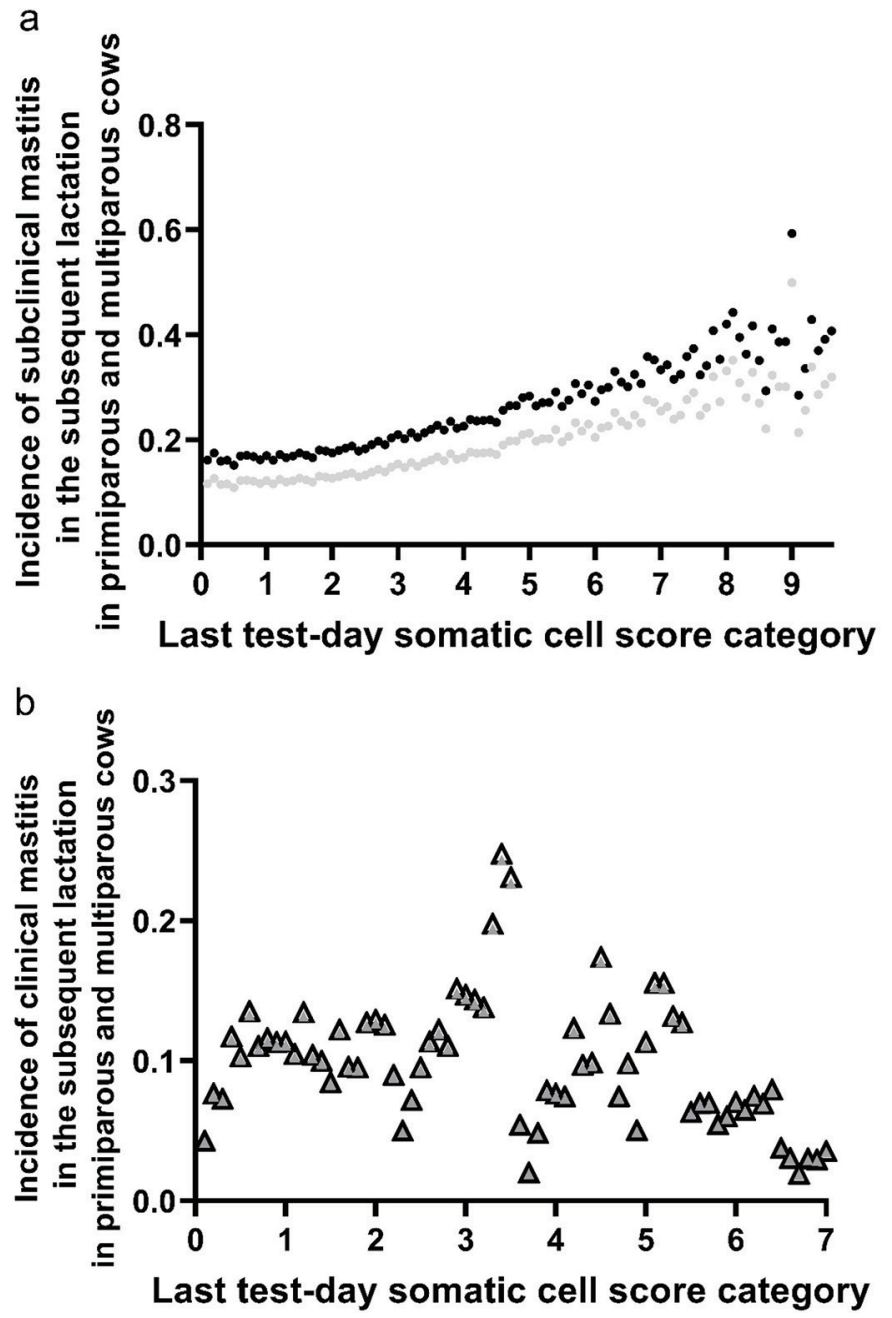

Figure 1. Output of the regression models on the incidence risk of (a) subclinical mastitis (SCM) in the first test-day (from 10 to 50 DIM) and (b) clinical mastitis (CM) up to 90 DIM per different last test-day SCS for cows receiving antibiotics at dry-off. Gray dots (SCM, a) and gray triangles (CM, b) represent primiparous cows, and black dots (SCM, a) and black triangles (CM, b) represent multiparous cows. The last SCS ranges from 0.1 to 9.6. The incidence of subclinical and clinical mastitis ranges from 0.0 to 1.0.

the dry period for primiparous and multiparous cows, and thereby the TCMD (Figure 3).

Use of Antibiotics. The ADDD around the dry period in economic optimal scenarios was $2.0,2.1$, and 2.2 for herds with low, medium, and high BTSCC (Table 2). Compared with BDCT scenarios, the ADDD around the dry period in the economic optimal scenarios was reduced by $31 \%, 29 \%$, and $26 \%$. If no antibiotics are used for DCT, ADDD would be reduced by $89 \%$ for all BTSCC herds.

Incidence of Subclinical and Clinical Mastitis. The incidence of first test-day SCM and CM up to 
a

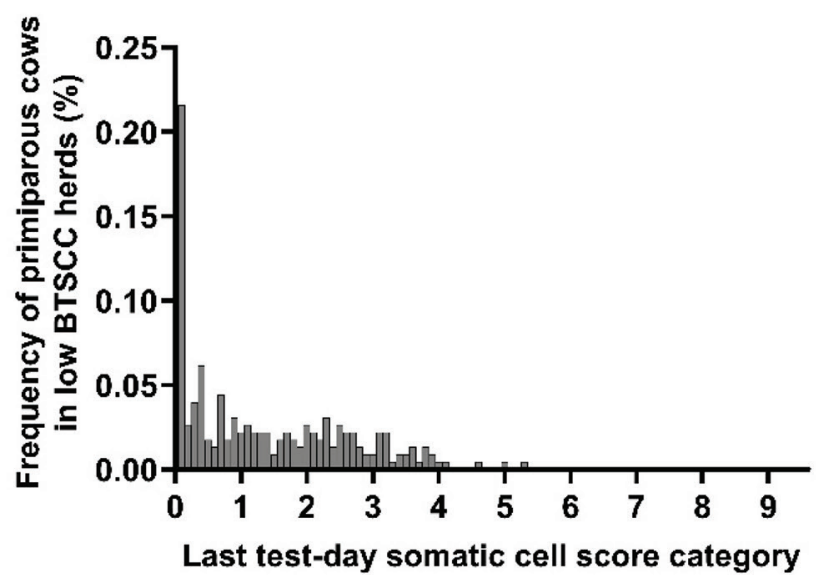

$\mathrm{C}$

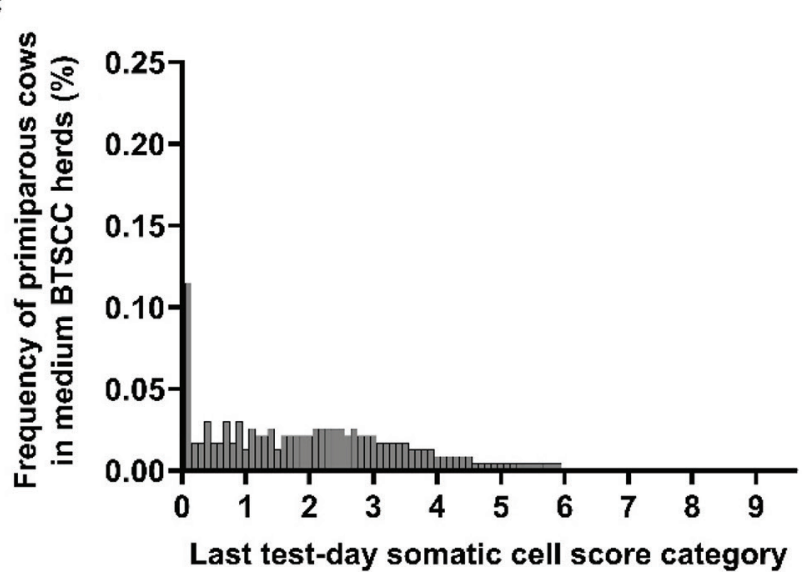

e

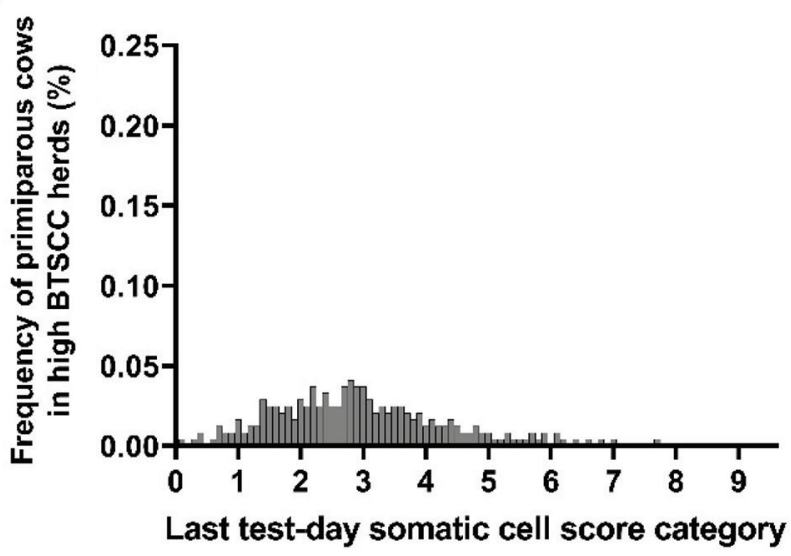

b

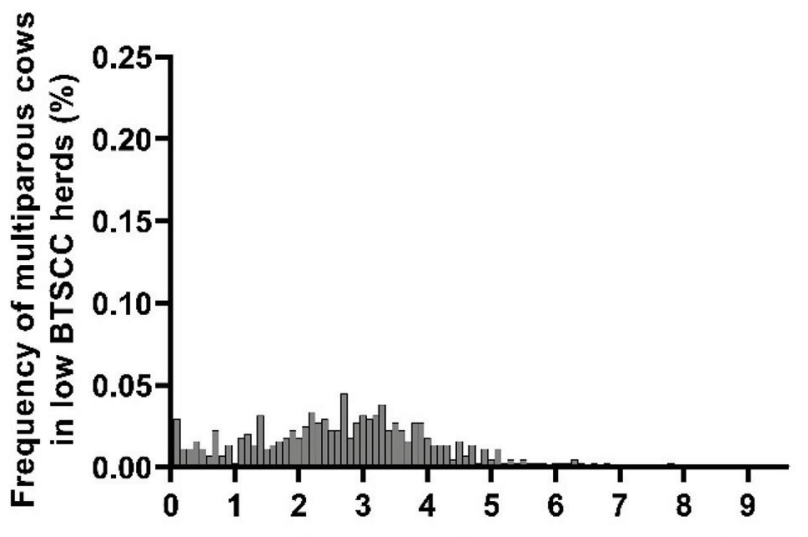

Last test-day somatic cell score category

d

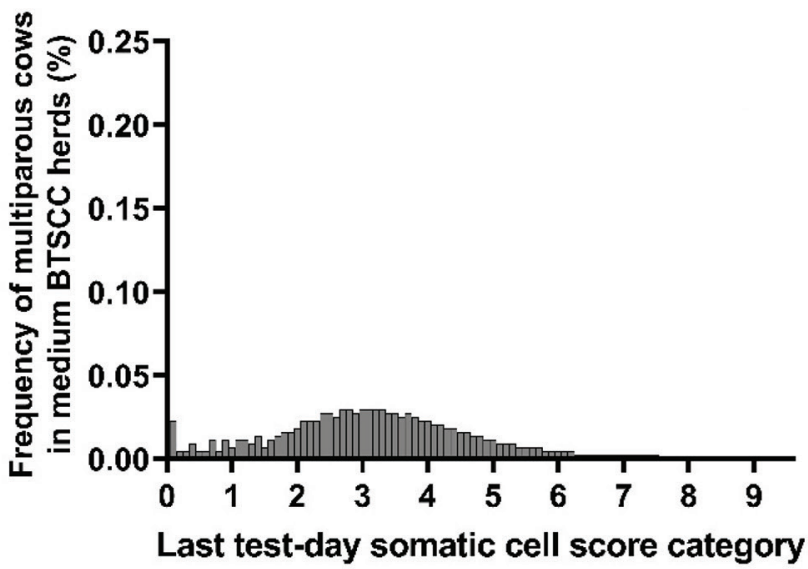

f

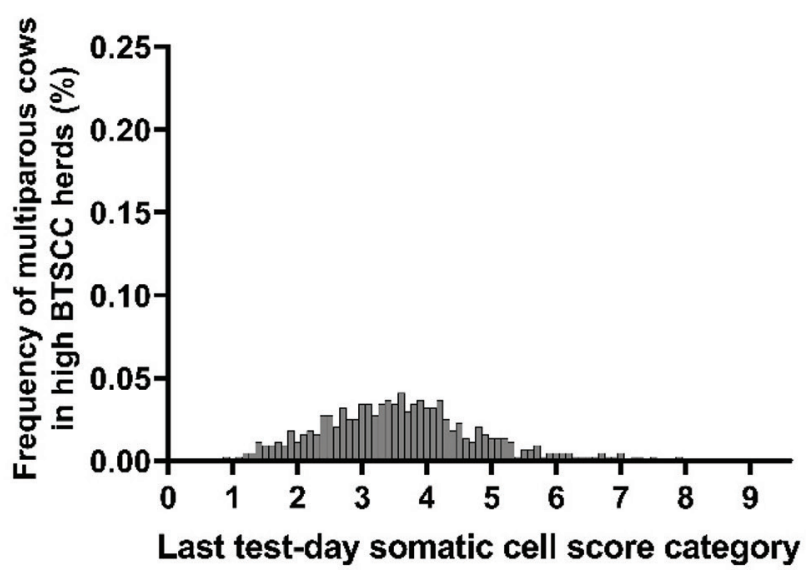

Figure 2. Distribution (frequency percentage) of primiparous and multiparous dairy cows per last test-day SCS for 3 different bulk tank somatic cell count (BTSCC) for simulated herds. Simulated herds were classified as low $(121,009-164,710$ cells/mL), medium (188,782-222,688 cells/mL), and high $(257,941-373,702$ cells $/ \mathrm{mL})$ BTSCC.

90 DIM under economic optimal allocation of antibiotics at dry-off are also presented in Table 2. On these scenarios, the incidences of SCM (primiparous and multiparous) were $22.6 \%$ and $21.5 \%$ (low BTSCC), $23.1 \%$ and $23.1 \%$ (medium BTSCC), and $24.6 \%$ and
$23.9 \%$ (high BTSCC). We found that CM had a similar behavior with $11.1 \%$ and $11.5 \%$ (low BTSCC), $11.9 \%$ and $11.2 \%$ (medium BTSCC), and $12.4 \%$ and $11.4 \%$ (high BTSCC) of cows developing CM up to 90 DIM in the subsequent lactation. 


\section{Sensitivity Analysis}

Milk Price. As milk prices increased, so did the TCMD and the percentage of cows receiving antibiotics at dry-off (Table 3). For instance, when milk prices were low $(\$ 0.30 / \mathrm{kg})$ and all the other inputs of the model were kept as in the default scenario, the TCMD under economic optimal allocation of antibiotics at dry-off in medium-BTSCC herds was $\$ 30,170 /$ herd per year. This was $\$ 1,645$ less per herd per year than for the BDCT scenario. In this scenario, $5 \%$ and $71 \%$ of the primiparous and multiparous cows were treated with antibiotics at dry-off, and ADDD was reduced by $47 \%$ compared with the BDCT scenario. The incidences of SCM were $26.7 \%$ and $25.5 \%$, and CM incidence were $12.9 \%$ and $12.0 \%$, for primiparous and multiparous. However, when milk price was high $(\$ 0.50 / \mathrm{kg})$, the TCMD under economic optimal allocation of antibiotics at dry-off for medium-BTSCC herds was only $\$ 293$ / herd per year less compared with the BDCT scenario. In this scenario, $70 \%$ and $97 \%$ of the primiparous and multiparous cows received antibiotics at dry-off. Total ADDD was 2.6 , a reduction of $11 \%$ compared with the BDCT scenario.

Antibiotics Cost. Low antibiotics costs favored the use of BDCT (Table 3). When dry-off antibiotics were $\$ 2$ /tube, the difference between TCMD under economic optimal allocation of antibiotics at dry-off and BDCT was small for all BTSCC herds $(\$ 120, \$ 90$, and $\$ 40 /$ herd per year, for low-, medium-, and high-BTSCC herds). By contrast, high antibiotics costs reduced the use of antibiotics, and differences between economic optimal and BDCT scenarios were $\$ 2,790, \$ 2,750$, and $\$ 2,620$ / herd per year for herds with low, medium, and high BTSCC. For instance, in the economic optimal scenario for medium-BTSCC herds, when the antibiotics price was low ( $\$ 2$ tube), $83 \%$ and $97 \%$ of the primiparous and multiparous cows received antibiotics at dry-off,

Table 2. Economic optimal scenario (lowest total cost of mastitis around the dry period), blanket dry cow therapy (BDCT), and no dry cow therapy (No DCT) scenarios of total cost of mastitis around the dry period (TCMD) for 1,000-cow herds with low, medium, and high bulk tank SCC (BTSCC)

\begin{tabular}{|c|c|c|c|c|c|c|}
\hline Item & \multicolumn{2}{|c|}{ Economic optimal } & \multicolumn{2}{|c|}{$\mathrm{BDCT}$} & \multicolumn{2}{|c|}{ No DCT } \\
\hline \multicolumn{7}{|l|}{ Low BTSCC } \\
\hline Cost $(\$ /$ cow per year $)$ & \multicolumn{2}{|c|}{37.3} & \multicolumn{2}{|c|}{38.0} & \multicolumn{2}{|c|}{42.9} \\
\hline $\operatorname{ADDD}^{1}$ (per cow) & \multicolumn{2}{|c|}{2.01} & \multicolumn{2}{|c|}{2.90} & \multicolumn{2}{|c|}{0.32} \\
\hline Cow receiving aa ${ }^{2}$ at dry-off $(\%)$ & \multicolumn{2}{|c|}{66.6} & \multicolumn{2}{|c|}{100} & \multicolumn{2}{|r|}{0} \\
\hline ADDD (per dry cow) & 1.14 & 3.92 & 4.28 & 4.33 & 0.28 & 0.57 \\
\hline Incidence risk of $\mathrm{SCM}^{3}(\%)$ & 22.6 & 21.5 & 12.8 & 20.2 & 25.7 & 32.3 \\
\hline Incidence risk of $\mathrm{CM}^{4}(\%)$ & 11.1 & 11.5 & 9.2 & 11.2 & 12.0 & 19.0 \\
\hline \multicolumn{7}{|l|}{ Medium BTSCC } \\
\hline Total cost $(\$ /$ herd $)$ & \multicolumn{2}{|c|}{38,085} & \multicolumn{2}{|c|}{38,781} & \multicolumn{2}{|c|}{43,685} \\
\hline Cost $(\$ /$ cow per year $)$ & \multicolumn{2}{|c|}{38.1} & \multicolumn{2}{|c|}{38.8} & \multicolumn{2}{|c|}{43.7} \\
\hline ADDD (per cow) & \multicolumn{2}{|c|}{2.07} & \multicolumn{2}{|c|}{2.93} & \multicolumn{2}{|c|}{0.34} \\
\hline Incidence risk of CM (\%) & 11.9 & 11.2 & 10.2 & 10.9 & 13.2 & 18.6 \\
\hline High BTSCC & & & & & & \\
\hline Total cost $(\$ /$ herd $)$ & 39,3 & & 39,8 & & 45,1 & \\
\hline Cost ( $\$ /$ cow per year $)$ & & 9.3 & & 9.9 & & 45.2 \\
\hline ADDD (per cow) & & 2.18 & & 2.95 & & 0.35 \\
\hline Cow receiving aa at dry-off $(\%)$ & & 1.9 & & & & 0 \\
\hline Cost $(\$ /$ dry cow $)$ & 55.1 & 59.1 & 56.9 & 59.3 & 56.3 & 71.8 \\
\hline Cow receiving aa at dry-off $(\%)$ & 38 & 89 & 100 & 100 & 0 & 0 \\
\hline ADDD (per dry cow) & 1.89 & 3.91 & 4.32 & 4.33 & 0.42 & 0.57 \\
\hline Incidence risk of SCM (\%) & 24.6 & 23.9 & 15.2 & 22.3 & 30.4 & 35.7 \\
\hline Incidence risk of CM (\%) & 12.4 & 11.4 & 10.8 & 11.1 & 14.1 & 18.9 \\
\hline
\end{tabular}

${ }^{1} \mathrm{ADDD}=$ animal-defined daily dosage.

${ }^{2}$ aa $=$ antibiotics.

${ }^{3}$ Incidence risk of subclinical mastitis in the first test-day after calving.

${ }^{4}$ Incidence risk of clinical mastitis in the first 90 DIM. 
and ADDD was reduced by only $7 \%$ compared with BDCT. At $\$ 5 /$ tube, only $5 \%$ of the primiparous and $67 \%$ of the multiparous received antibiotics at dry-off, and ADDD was reduced by $49 \%$.

Risk Ratio of the Incidence of Subclinical and Clinical Mastitis in the Subsequent Lactation When Only Teat Sealant Was Used. The risk ratio of the incidence of SCM and $\mathrm{CM}$ in the subsequent lactation when no antibiotics and only internal teat sealant was used at dry-off affected the TCMD (Table 4). When the risk ratio was 1 , indicating no difference in the incidence of SCM and $\mathrm{CM}$ in the subsequent lactation between cows receiving both antibiotics and internal teat sealants and cows receiving only internal teat sealants, no cows received antibiotics at dry-off, nomic optimal TCMD was the lowest and was $\$ 9,050$, $\$ 9,120$, and $\$ 9,170 /$ herd per year less when compared with BDCT scenarios in herds with low, medium, and high BTSCC. The ADDD was minimum and was $93 \%$, $93 \%$, and $92 \%$ (low, medium, and high BTSCC) less in the economic optimal scenarios compared with BDCT. As the risk ratio increased, TCMD increased, the percentage of primiparous and multiparous cows receiving antibiotics at dry-off increased, and the overall use of antibiotics increased. When the risk ratio was 1.3 , despite the reduction in ADDD by $76 \%, 73 \%$, and $68 \%$ when economic optimal scenarios were compared with BDCT scenarios, the incidence of SCM was the highest for primiparous and multiparous cows in low- $(16.5 \%$
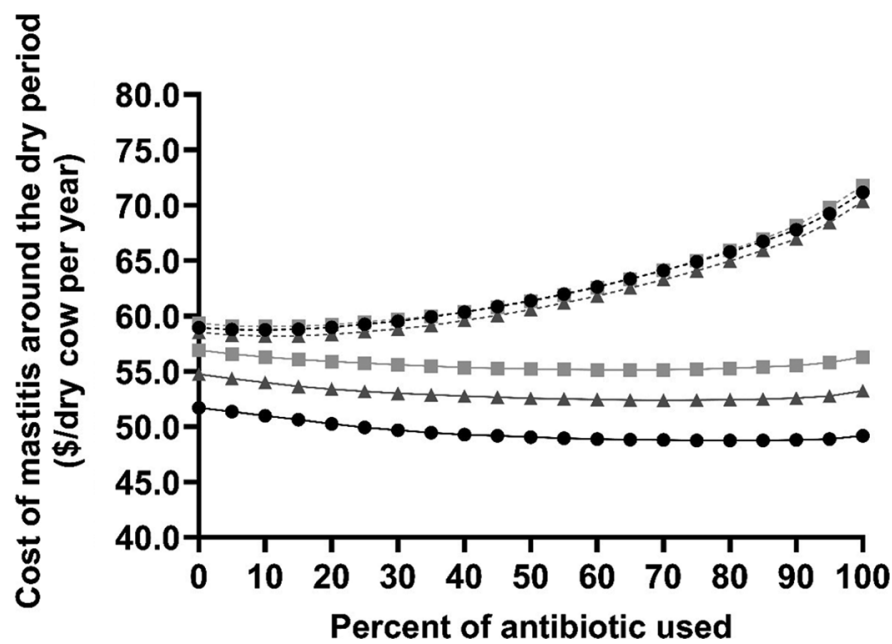

Figure 3. Total cost of mastitis around the dry period $(\$ /$ dry cow per year) for economic optimal allocation of antibiotics while restricting the amount of antibiotics used from 0 to $100 \%$ per simulated herd and parity. Solid lines represent primiparous cows; dashed lines represent multiparous cows. Circle, triangle, and square markers represent herds with low (121,009-164,710 cells/mL), medium (188,782-222,688 cells/mL), and high (257,941-373,702 cells/mL) bulk tank somatic cell counts, respectively. regardless of the herd BTSCC. In these scenarios, eco-

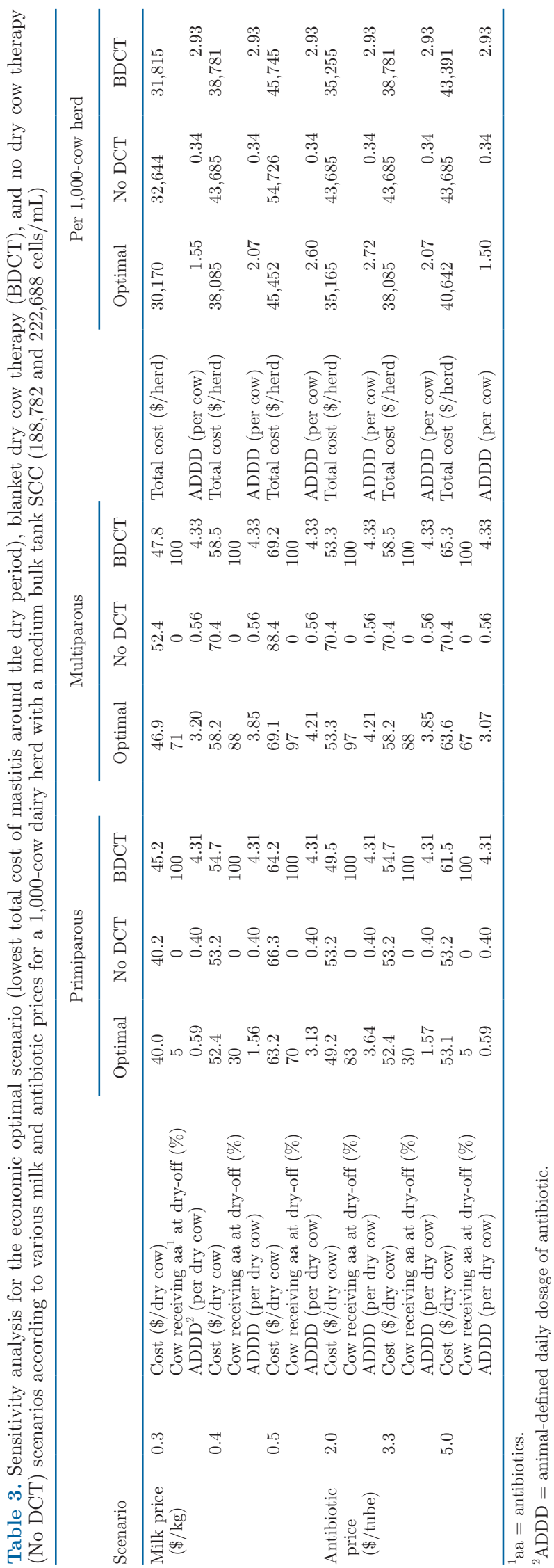

Journal of Dairy Science Vol. 104 No. 8, 2021 
and $24.7 \%$ ), medium- (17.4\% and $26.2 \%$ ), and highBTSCC herds (19.0\% and 27.0\%), respectively. The same pattern was observed for the incidence of CM for primiparous and multiparous cows in low- $(11.8 \%$ and $13.2 \%)$, medium- (12.6\% and $12.9 \%)$, and high-BTSCC herds $(13.2 \%$ and $12.9 \%)$. Increasing the incidence ratio to 2.0 or 2.55 favored the use of BDCT.

\section{DISCUSSION}

Our work showed that opportunities exist to implement SDCT in large US dairy herds, supporting the conclusions of other US studies (Vasquez et al., 2018; Rowe et al., 2020a,b). To our knowledge, this is the first study that assessed the economics of SDCT and its impacts on antibiotic use in large dairy herds in the US. The economic results from this study may help farmers in their decision-making process (Lam et al., 2017). In our study, the use of SDCT had the lowest costs of mastitis around the dry period for all herds, independent of their BTSCC status, similar to other economic analyses from literature (Huijps and Hogeveen, 2007; Scherpenzeel et al., 2016; Scherpenzeel et al., 2018). Although the economic benefits may be perceived as small or of little impact for large herds, our results showed a potential for a reduction in the use of antibiotics in dairy herds with no negative economic effects, similar to results observed in the Netherlands (Vanhoudt et al., 2018).

In this study, we used an LP model to evaluate, from an economic point of view, the optimal use of antibiotics at dry-off. Linear programming is an optimization method, and although they appear to be similar, an optimization model is distinctly different from a simulation model. An economic optimization model, such as an LP model, determines the optimal (best) allocation of resources (e.g., antibiotics) and in that way provides a recommendation for the optimal scenario. An economic simulation model, such as the stochastic simulation model used by Huijps and Hogeveen (2007) allows users to determine how the system responds to a given allocation of resources and can be used to evaluate several user-defined scenarios. Because of a lack of an objective function, simulation models provide more flexibility and opportunity to model biological complexity than optimization models. Hence, in this research we did not impose any restriction on which cows should or should not receive antibiotics at dry-off. We allowed the model to choose the cows based on the risk of SCM and $\mathrm{CM}$ in the subsequent lactation, the costs associated with using antibiotics at dry-off, and the costs associated with the risks of SCM and CM in the subsequent lactation. This economic optimal selection of cows may differ from approaches in which the criteria for cows that should receive antibiotics are defined a priori (Scherpenzeel et al., 2014; Cameron et al., 2015; Vasquez et al., 2018; Rowe et al., 2020a). Therefore, the optimal proportion of cows to be treated with antibiotics at dry-off will change when prices change. For instance, with higher milk prices, prevention of occurrence of SCM or CM becomes more valuable, and, as a consequence, it will be economically optimal to treat more cows with antibiotics at dry-off. Similarly, lower prices of antibiotics, and a higher probability of SCM and $\mathrm{CM}$ in the subsequent lactation when only internal teat sealants were used at dry-off, will also lead to an economically optimal situation consisting of a higher proportion of cows to be treated with antibiotics at dryoff. The other way around, higher prices of antibiotics, lower costs of SCM, CM, or both, or a lower risk ratio, will result in an economically optimal situation with a lower proportion of cows to be treated with antibiotics at dry-off. This would mean that farmers, when they aim for profit maximization, may adjust their selective DCT strategy to currrent and herd-specific price levels.

The incidence of mastitis influenced the choice of the economic optimal DCT scenario, because the TCMD was greatly influenced by the costs of mastitis in the subsequent lactation. Although we did not perform a sensitivity analysis for the cost of mastitis per se, milk price can be used as a proxy for it, as milk losses were responsible for $74 \%$ of the costs of clinical and $100 \%$ of the costs of subclinical mastitis in the subsequent lactation (results not shown). For instance, for herds with a medium BTSCC, when milk price was high (meaning that the costs of SCM and CM mastitis were also high, $\$ 28.7$ and $\$ 378.5 /$ case, respectively), the ADDD of the economic optimal scenario was $67 \%$ greater than the ADDD for the economic optimal scenario with low milk prices (and costs of SCM and CM mastitis were also low, $\$ 13.9$ and $\$ 212.0 /$ case, respectively).

In this study we aimed to mimic the dry-off management of large US dairy herds (herds with $>500$ lactating dairy cows). We used data from California, which is only one region where many large dairy herds are located. Because of the large similarity in mastitis management among large US dairy herds (Oliveira et al., 2013; Rowe et al., 2020 a,b), we do believe that our results are applicable for herds with similar management in all regions of the US. Differences may exist in probability of mastitis infections during the dry period between regions because of climatic circumstances, but we could not find any research supporting this. Of course, individual herds may differ in probabilities of cure of IMI at dry-off or probability of IMI during the dry period, as well as in prices and costs of mastitits 
Hommels et al.: ANTIBIOTIC USE AND ECONOMICS OF SELECTIVE DRY COW THERAPY

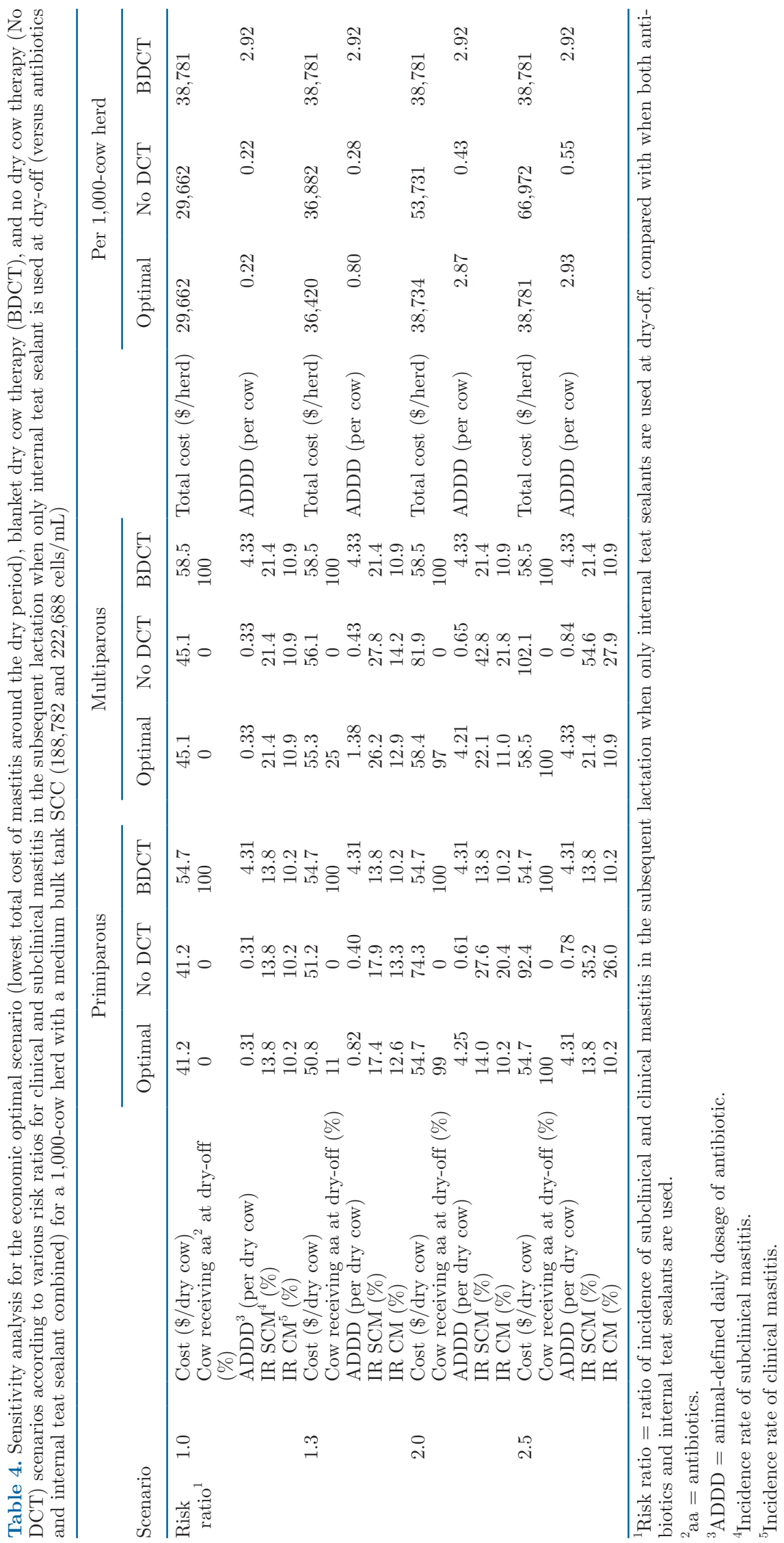


cases. Therefore we do advise that herds make their own considerations when designing a selective DCT strategy. An optimization model such as the one described in this paper may be helpful for this.

Because most large US dairy herds use BDCT in combination with teat sealant (USDA-NAHMS, 2014), we had to make important assumptions. In doing so, we took a conservative approach. We assumed that large US dairy herds moving from BDCT to SDCT will persist in using teat sealant for each cow at dry-off while selectively using antibiotics. Furthermore, we assumed that when teat sealant was used at dry-off, the risk of $\mathrm{SCM}$ and $\mathrm{CM}$ in the subsequent lactation for cows in each class of last test-day SCS would be greater than when antibiotics and teat sealant were used concomitantly (Scherpenzeel et al., 2018). The increased risk ratios reported by Scherpenzeel et al. (2018) may be a result of new IMI during the dry period in combination with reduced cure rates, as they did not use teat sealants. In low-risk cows, the use of internal teat sealant has been shown to be equal to or better than the use of antibiotics at dry-off in terms of postpartum udder health (Huxley et al., 2002; Krömker et al., 2014; McParland et al., 2019), and no negative effects have been reported when teat sealants are applied hygienically (Bonsaglia et al., 2017). In a recent meta-analysis by Winder et al. (2019) comparing the efficacy of BDCT versus SDCT, the overall risk ratio for IMI at calving was 1.34 . When only studies that used teat sealant at dry-off were considered, the risk ratio was 1.09. Thosee authors indicated that despite the small number of trials, the use of teat sealants likely explains a large portion of the heterogeneity observed in their analysis. In the US, recent studies have shown no differences in the risk ratios of SCM and CM for groups of cows receiving BDCT and SDCT (Vasquez et al., 2018; Rowe et al., 2020a); however, these researchers assumed a noninferiority of 10\% (Rowe et al., 2020a,b). Previous reports on the success of SDCT in Norway (Østerås and Sølverød, 2009) and the Netherlands (Vanhoudt et al., 2018) did not report the use of teat sealant, but other approaches for selecting cows at dry-off are proposed. Thus, more studies on the dynamics of intramammary infection around the dry period comparing the use of teat sealant and no treatment in low-risk cows are needed.

To address the lack of consistency in the literature regarding risk ratio for new IMI in the subsequent lactation according to the last SCS when internal teat sealants are used, we ran a sensitivity analysis with different scenarios of various risk ratios. In this analysis, we assumed no difference in the incidence of new IMI during the dry period for the cows receiving antibiotics and teat sealant, or teat sealant only, at dry-off (Winder et al., 2019). Therefore, the difference in the incidence of SCM and CM in the subsequent lactation was assumed to be based on the IMI cure rate during the dry period. We derived the risk ratio based on different cure rates reported in the literature (Supplemental File S1, https://doi.org/10.6084/m9.figshare.14428202; Huxley et al., 2002; Halasa et al., 2009; Bradley et al., 2010). At a risk ratio of 1.3 (Winder et al., 2019), antibiotics used around the dry period could be reduced by $72 \%$ on average, consistent with other studies $(85 \%$, Scherpenzeel et al., 2014; 60\%, Vasquez et al., 2018; $55 \%$, Rowe et al. 2020a). Nonetheless, we opted to be cautious and use a more conservative estimate in our default scenario, likely resulting in an overestimation of the TMCD. The dynamics of intramammary infections around the dry period should be taken into consideration when a dry-off program is designed.

Each herd and case of mastitis is unique (Gröhn et al., 2004; van Soest et al., 2019). The risks for SCM and $\mathrm{CM}$ in the subsequent lactation were derived from the incidences calculated using regression models performed in the data obtained from DHIA and the herds' management programs, according to their last test-day before dry-off SCS, and it is possible that these herds have better overall mastitis management and lower incidence of mastitis. The calculated incidence of CM in early lactation for cows with a last test-day SCS above 5.5 showed a downward trend. Biologically, this downward trend is difficult to explain. It could be due to a bias in the data set, with cows with high last test-day SCS leaving the herd earlier and not having cases of SCM or CM reported in the system, or possibly the IMI (and therefore the high SCS at dry-off) is caused by a pathogen that is more susceptible to cure at dry-off when receiving antibiotics (Huxley et al., 2002; Halasa et al., 2009; Bradley et al., 2010). Moreover, differences between mastitis-causing pathogens regarding their ability to develop SCC at the start of the next lactation cannot be excluded. As our regression models for the incidence of SCM and $\mathrm{CM}$ were not linear, neither was the distribution of cows per category of last test-day SCS for the simulated herds, we observed slightly smaller overall incidence risk of $\mathrm{CM}$ and use of antibiotics for multiparous in herds with medium BTSCC compared with herds with low and high BTSCC. Nonetheless, these differences were small and reflect the results of our models.

Efforts are being made worldwide to reduce the use of antibiotics in humans as well as in animals (CDC, 2014; WHO, 2018; Aidara-Kane et al., 2018). As a result, efforts are also being made to reduce the prophylactic use of antibiotics at dry-off in many European countries, and BDCT has been banned in a relatively small number of European countries (Santman-Berends et al., 2016). In this study, we demonstrated that a complete 
removal of antibiotics at dry-off is not economically efficient, as it incurs an increased TCMD. In addition, a complete removal of antibiotics at dry-off represents an animal welfare issue due to increased CM occurrence in the subsequent lactation (Petersson-Wolfe et al., 2018). However, regardless of the herd BTSCC, we demonstrated that the implementation of an SDCT approach results in a considerable reduction in the use of antibiotics without economic harm. In 2019, the average BTSCC for US herds participating in the DHIA testing program was 187,000 (Norman et al., 2020). Extrapolating the results of our study, this would indicate an opportunity to reduce the use of antibiotics around the dry period by $29 \%$ in the US. Such a reduction is feasible (Vanhoudt et al., 2018).

Finally, we did not intend to provide a recommendation on selection criteria for cows in an SDCT program. Rather, we provided economic information on SDCT to improve decision-making. Although we combined data from multiple herds and years representative of large herds in the western US, we did not model individual mastitis pathogens and their unique epidemiology, such as the risk associated with shedding of bacteria (Swinkels et al., 2005) and the risk for developing SCM and $\mathrm{CM}$ in the next lactation. This is an opportunity for further refinement of this economic analysis and the resulting reduction of antibiotic use.

\section{CONCLUSIONS}

Based on the calculations made with our optimization model, it is economically feasible to implement SDCT in large herds in the US, with a potential to reduce the use of antibiotics around the dry period by $29 \%$ in a conservative scenario. The largest reduction in the use of antibiotics when applying SDCT could be made in primiparous cows. When the percentage of cows receiving antibiotics at dry-off was gradually restricted, the incidence of both SCM and CM increased. Results were dependent on assumptions, which were based on limited literature on new intramammary infection and cure rates around the dry period when only internal teat sealants are used. The epidemiology of mastitis pathogens and the dry cow management in each herd should be considered before an SDCT strategy is implemented.

\section{ACKNOWLEDGMENTS}

This study was supported by the California Department of Food and Agriculture, award no. 19-0722-000SG, "Development of an economic tool to optimize mastitis management programs in California," to F. C. Ferreira. The authors thank Bill VerBoort (AgriTech,
Visalia, CA) and the California dairy farmers for providing the data for this study. The authors declare no conflict of interest.

\section{REFERENCES}

Aidara-Kane, A., F. J. Angulo, J. M. Conly, Y. Minato, E. K. Silbergeld, S. A. McEwen, P. J. Collignon, and WHO Guideline Development Group. 2018. World Health Organization (WHO) guidelines on use of medically important antimicrobials in foodproducing animals. Antimicrob. Resist. Infect. Control 7:7. https: //doi.org/10.1186/s13756-017-0294-9.

Berry, E. A., and J. E. Hillerton. 2002. The effect of selective dry cow treatment on new intramammary infections. J. Dairy Sci. 85:112121. https://doi.org/10.3168/jds.S0022-0302(02)74059-9.

Bonsaglia, E. C. R., M. S. Gomes, I. F. Canisso, Z. Zhou, S. F. Lima, V. L. M. Rall, G. Oikonomou, R. C. Bicalho, and F. S. Lima. 2017. Milk microbiome and bacterial load following dry cow therapy without antibiotics in dairy cows with healthy mammary gland. Sci. Rep. 7:8067. https://doi.org/10.1038/s41598-017-08790-5.

Bradley, A. J., J. E. Breen, B. Payne, P. Williams, and M. J. Green. 2010. The use of a cephalonium containing dry cow therapy and an internal teat sealant, both alone and in combination. J. Dairy Sci. 93:1566-1577. https://doi.org/10.3168/jds.2009-2725.

CA-DIR (California Department of Industrial Relations). 2020. Minimum Wage. Accessed Jun. 10, 2020. https://www.dir.ca.gov/dlse/ faq_minimumwage.htm.

Cameron, M., G. P. Keefe, J. P. Roy, H. Stryhn, I. R. Dohoo, and S. L. McKenna. 2015. Evaluation of selective dry cow treatment following on-farm culture: Milk yield and somatic cell count in the subsequent lactation. J. Dairy Sci. 98:2427-2436. https://doi.org/ $10.3168 /$ jds.2014-8876.

CDC (Center for Disease Control and Prevention). 2014. U.S. National Strategy for Combating Antibiotic-Resistant Bacteria (National Action Plan). Accessed Apr. 4, 2020. https://www.cdc.gov/ drugresistance/us-activities/national-action-plan.html.

CDCB (Council on Dairy Cattle Breeding). 2017. Summary of 2017 DHI herd averages, DHI report K-3. Accessed Jun. 27, 2020. https: //queries.uscdcb.com/publish/dhi/dhi18/hax.html.

Dingwell, R. T., K. E. Leslie, Y. H. Schukken, J. M. Sargeant, and L. L. Timms. 2003. Evaluation of the California Mastitis Test to detect an intramammary infection with a major pathogen in early lactation dairy cows. Can. Vet. J. 44:413-415.

Dodd, F. H., D. R. Westgarth, F. K. Neave, and R. G. Kingwill. 1969. Mastitis - The strategy of control. J. Dairy Sci. 52:689-695. https: //doi.org/10.3168/jds.S0022-0302(69)86631-2.

Dohoo, I., W. Martin, and H. Stryhn. 2009. Veterinary Epidemiologic Research. 2nd ed. VER Inc.

Dufour, S., V. Wellemans, J.-P. Roy, P. Lacasse, A. Ordonez-Iturriaga, and D. Francoz. 2019. Non-antimicrobial approaches at drying-off for treating and preventing intramammary infections in dairy cows. Part 1. Meta-analyses of efficacy of using an internal teat sealant without a concomitant antimicrobial treatment. Anim. Health Res. Rev. 20:86-97. https://doi.org/10.1017/S1466252319000070.

Ferreira, F. C., J. S. Clay, and A. De Vries. 2020. Distribution of seasonality of calving patterns and milk production in dairy herds across the United States. J. Dairy Sci. 103:8161-8173. https://doi .org/10.3168/jds.2019-18138.

Gonçalves, J. L., C. Kamphuis, C. M. M. R. Martins, J. R. Barreiro, T. Tomazi, A. H. Gameiro, H. Hogeveen, and M. V. dos Santos. 2018. Bovine subclinical mastitis reduces milk yield and economic return. Livest. Sci. 210:25-32. https://doi.org/10.1016/ j.livsci.2018.01.016.

Green, M. J., L. E. Green, G. F. Medley, Y. H. Schukken, and A. J. Bradley. 2002. Influence of dry period bacterial intramammary infection on clinical mastitis in dairy cows. J. Dairy Sci. 85:25892599. https://doi.org/10.3168/jds.S0022-0302(02)74343-9.

Gröhn, Y. T., S. W. Eicker, V. Ducrocq, and J. A. Hertl. 1998. Effect of diseases on the culling of Holstein dairy cows in New York 
State. J. Dairy Sci. 81:966-978. https://doi.org/10.3168/jds.S0022 $-0302(98) 75657-7$.

Gröhn, Y. T., D. J. Wilson, R. N. González, J. A. Hertl, H. Schulte, G. Bennett, and Y. H. Schukken. 2004. Effect of pathogen-specific clinical mastitis on milk yield in dairy cows. J. Dairy Sci. 87:33583374. https://doi.org/10.3168/jds.S0022-0302(04)73472-4.

Halasa, T., M. Nielen, A. P. W. De Roos, R. Van Hoorne, G. de Jong, T. J. G. M. Lam, T. van Werven, and H. Hogeveen. 2009. Production loss due to new subclinical mastitis in Dutch dairy cows estimated with a test-day model. J. Dairy Sci. 92:599-606. https:/ /doi.org/10.3168/jds.2008-1564.

Hogeveen, H., W. Steeneveld, and C. A. Wolf. 2019. Production diseases reduce the efficiency of dairy production: A review of the results, methods, and approaches regarding the economics of mastitis. Annu. Rev. Resour. Econ. 11:289-312. https://doi.org/10 .1146/annurev-resource-100518-093954.

Huijps, K., and H. Hogeveen. 2007. Stochastic modeling to determine the economic effects of blanket, selective, and no dry cow therapy. J. Dairy Sci. 90:1225-1234. https://doi.org/10.3168/jds.S0022 -0302(07)71611-9.

Huijps, K., T. J. Lam, and H. Hogeveen. 2008. Costs of mastitis: Facts and perception. J. Dairy Res. 75:113-120. https://doi.org/ 10.1017/S0022029907002932.

Huxley, J. N., M. J. Green, L. E. Green, and A. J. Bradley. 2002. Evaluation of the efficacy of an internal teat sealer during the dry period. J. Dairy Sci. 85:551-561. https://doi.org/10.3168/jds .S0022-0302(02)74108-8.

Krömker, V., N. T. Grabowski, and J. Friedrich. 2014. New infection rate of bovine mammary glands after application of an internal teat seal at dry-off. J. Dairy Res. 81:54-58. https://doi.org/10 $.1017 /$ S0022029913000599.

Kuipers, A., W. J. Koops, and H. Wemmenhove. 2016. Antibiotic use in dairy herds in the Netherlands from 2005 to 2012. J. Dairy Sci. 99:1632-1648. https://doi.org/10.3168/jds.2014-8428.

Lam, T. J. G. M., J. Jansen, and R. J. Wessels. 2017. The RESET mindset model applied on decreasing antibiotic usage in dairy cattle in the Netherlands. Ir. Vet. J. 70:5. https://doi.org/10.1186/ s13620-017-0085-X.

Lam, T. J. G. M., Y. H. Schukken, J. H. van Vliet, F. J. Grommers, M. J. Tielen, and A. Brand. 1997. Effect of natural infection with minor pathogens on susceptibility to natural infection with major pathogens in the bovine mammary gland. Am. J. Vet. Res. $58: 17-22$.

Makovec, J. A., and P. L. Ruegg. 2003. Results of milk samples submitted for microbiological examination in Wisconsin from 1994 to 2001. J. Dairy Sci. 86:3466-3472. https://doi.org/10.3168/jds .S0022-0302(03)73951-4.

McParland, S., P. G. Dillon, J. Flynn, N. Ryan, S. Arkins, and A. Kennedy. 2019. Effect of using internal teat sealant with or without antibiotic therapy at dry-off on subsequent somatic cell count and milk production. J. Dairy Sci. 102:4464-4475. https://doi.org/10 $.3168 /$ jds.2018-15195.

Norman, H. D., F. L. Guinan, L. M. Walton, and J. Dürr. 2020. Somatic cell counts of milk from 2019 DHI herds. CDCB (Council on Dairy Cattle Breeding). Accessed Dec. 12, 2020. https://queries .uscdcb.com/publish/dhi/current/sccx.html.

Norman, H. D., R. H. Miller, J. R. Wright, and G. R. Wiggans. 2000. Herd and state means for somatic cell count from dairy herd improvement. J. Dairy Sci. 83:2782-2788. https://doi.org/10.3168/ jds.S0022-0302(00)75175-7.

NRC (National Research Council). 2001. Nutrient Requirements of Dairy Cattle. 7th rev. ed. National Academies Press.

Oliveira, L., C. Hulland, and P. L. Ruegg. 2013. Characterization of clinical mastitis occurring in cows on 50 large dairy herds in Wisconsin. J. Dairy Sci. 96:7538-7549. https://doi.org/10.3168/jds $.2012-6078$.

Østerås, O., and L. Sølverød. 2009. Norwegian mastitis control program. Ir. Vet. J. 62(Suppl. 4):S26-S33. https://doi.org/10.1186/ 2046-0481-62-S4-S26.

Overton, M. W., and K. C. Dhuyvetter. 2020. Symposium review. An abundance of replacement heifers: What is the economic impact of raising more than are needed? J. Dairy Sci. 103:3828-3837. https: //doi.org/10.3168/jds.2019-17143.

Patel, K., S. M. Godden, E. E. Royster, J. A. Timmerman, B. A. Crooker, and N. McDonald. 2017. Pilot study: Impact of using a culture-guided selective dry cow therapy program targeting quarter-level treatment on udder health and antibiotic use. Bov. Pract. 51:48-57.

Petersson-Wolfe, C. S., K. E. Leslie, and T. H. Swartz. 2018. An update on the effect of clinical mastitis on the welfare of dairy cows and potential therapies. Vet. Clin. North Am. Food Anim. Pract. 34:525-535. https://doi.org/10.1016/j.cvfa.2018.07.006.

Rollin, E., K. C. Dhuyvetter, and M. W. Overton. 2015. The cost of clinical mastitis in the first 30 days of lactation: An economic modeling tool. Prev. Vet. Med. 122:257-264. https://doi.org/10.1016/j .prevetmed.2015.11.006

Rowe, S. M., S. M. Godden, D. V. Nydam, P. J. Gorden, A. Lago, A. K. Vasquez, E. Royster, J. Timmerman, and M. J. Thomas. 2020a. Randomized controlled trial investigating the effect of 2 selective dry-cow therapy protocols on udder health and performance in the subsequent lactation. J. Dairy Sci. 103:6493-6503. https://doi .org/10.3168/jds.2019-17961.

Rowe, S. M., S. M. Godden, D. V. Nydam, A. Lago, A. K. Vasquez, E. Royster, and J. Timmerman. 2020b. Randomized equivalence study comparing the efficacy of 2 commercial internal teat sealants in dairy cows. J. Dairy Sci. 103:5398-5413. https://doi.org/ $10.3168 /$ jds.2019-17884.

Santman-Berends, I. M. G. A.. J. M. Swinkels, T. J. G. M. Lam, J. Keurentjes, and G. van Schaik. 2016. Evaluation of udder health parameters and risk factors for clinical mastitis in Dutch dairy herds in the context of a restricted antimicrobial use policy. J. Dairy Sci. 99:2930-2939. https://doi.org/10.3168/jds.2015-10398.

Scherpenzeel, C. G. M., I. E. M. den Uijl, G. van Schaik, R. G. M. Olde Riekerink, J. M. Keurentjes, and T. J. G. M. Lam. 2014. Evaluation of the use of dry cow antibiotics in low somatic cell count cows. J. Dairy Sci. 97:3606-3614. https://doi.org/10.3168/ jds.2013-7655.

Scherpenzeel, C. G. M., I. E. M. den Uijl, G. van Schaik, R. G. M. O. Riekerink, H. Hogeveen, and T. J. G. M. Lam. 2016. Effect of different scenarios for selective dry-cow therapy on udder health, antimicrobial use, and economics. J. Dairy Sci. 99:3753-3764. https: //doi.org/10.3168/jds.2015-9963.

Scherpenzeel, C. G. M., H. Hogeveen, L. Maas, and T. J. G. M. Lam. 2018. Economic optimization of selective dry cow treatment. J. Dairy Sci. 101:1530-1539. https://doi.org/10.3168/jds.2017-13076.

Schukken, Y. H., D. J. Wilson, F. Welcome, L. Garrison-Tikofsky, and R. N. Gonzalez. 2003. Monitoring udder health and milk quality using somatic cell counts. Vet. Res. 34:579-596. https://doi.org/10 .1051/vetres:2003028.

Swinkels, J. M., J. G. A. Rooijendijk, R. N. Zadoks, and H. Hogeveen. 2005. Use of partial budgeting to determine the economic benefits of antibiotic treatment of chronic subclinical mastitis caused by Streptococcus uberis or Streptococcus dysgalactiae. J. Dairy Res. 72:75-85. https://doi.org/10.1017/S0022029904000603.

USDA. 2018. Health and Management Practices on U.S. Dairy Operations, 2014. United States Department of Agriculture (USDA) Animal and Plant Health Inspection Sercivce (APHIS), Veterinary Services (VS), and National Animal Health Monitoring System (NAHMS). Accessed Feb. 12, 2021. https://www.aphis.usda.gov/ animal_health/nahms/dairy/downloads/dairy14/Dairy14_dr _PartIII.pdf.

USDA-NAHMS (United States Department of Agriculture, National Animal Health Monitoring System). 2014. Milk Quality, Milking Procedures, and Mastitis on U.S. Dairies, 2014. Accessed Dec. 12 , 2020. https://www.aphis.usda.gov/animal_health/nahms/dairy/ downloads/dairy14/Dairy14_dr_Mastitis.pdf.

USDA-ERS. 2019. Milk cost of production estimates. Accessed Jul. 25. 2020. https://www.ers.usda.gov/data-products/milk-cost-of -production-estimates/.

USDA-NASS. 2020. Agricultural prices. Accessed Dec. 12, 2020. https: //usda.library.cornell.edu/concern/publications/c821gj76b. 
van Soest, F. J. S., M. C. M. Mourits, I. Blanco-Penedo, J. Duval, N. Fall, M. Krieger, K. Sjöstrom, and H. Hogeveen. 2019. Farmspecific failure costs of production disorders in European organic dairy herds. Prev. Vet. Med. 168:19-29. https://doi.org/10.1016/j .prevetmed.2019.03.029.

Vanhoudt, A., K. van Hees-Huijps, A. T. M. van Knegsel, O. C. Sampimon, J. C. M. Vernooij, M. Nielen, and T. van Werven. 2018. Effects of reduced intramammary antimicrobial use during the dry period on udder health in Dutch dairy herds. J. Dairy Sci. 101:3248-3260. https://doi.org/10.3168/jds.2017-13555.

Vasquez, A. K., D. V. Nydam, C. Foditsch, M. Wieland, R. Lynch, S. Eicker, and P. D. Virkler. 2018. Use of a culture-independent on-farm algorithm to guide the use of selective dry-cow antibiotic therapy. J. Dairy Sci. 101:5345-5361. https://doi.org/10.3168/jds 2017-13807.

WHO (World Health Organization). 2018. Antibiotic resistance fact sheet. Accessed Apr. 4, 2020. https://www.who.int/news-room/ fact-sheets/detail/antibiotic-resistance.

Wilson, D. J., R. N. González, J. Hertl, H. F. Schulte, G. J. Bennett, Y. H. Schukken, and Y. T. Gröhn. 2004. Effect of clinical mastitis on the lactation curve: A mixed model estimation using daily milk weights. J. Dairy Sci. 87:2073-2084. https://doi.org/10.3168/jds .S0022-0302(04)70025-9.

Winder, C. B., J. M. Sargeant, D. F. Kelton, S. J. LeBlanc, T. F. Duffield, J. Glanville, H. Wood, K. J. Churchill, J. Dunn, M. d. Bergevin, K. Dawkins, S. Meadows, and A. M. O'Connor. 2019. Comparative efficacy of blanket versus selective dry-cow therapy: A systematic review and pairwise meta-analysis. Anim. Health Res. Rev. 20:217-228. https://doi.org/10.1017/S1466252319000306.

\section{ORCIDS}

Nina M. C. Hommels ๑ https://orcid.org/0000-0001-6863-5318 Fernanda C. Ferreira @ https://orcid.org/0000-0003-2387-2269

Bart H. P. van den Borne (® https://orcid.org/0000-0001-6248-4707

Henk T. Hogeveen ๑ https://orcid.org/0000-0002-9443-1412 